\title{
PK/PD Modeling to Assess Rifaximin Clinical Dosage in a Mouse Model of Staphylococcus aureus-Induced Mastitis
}

\section{OPEN ACCESS}

Edited by:

Nora Mestorino,

National University of La

Plata, Argentina

Reviewed by:

Pierre-Louis Toutain,

Ecole Nationale Vétérinaire de

Toulouse, France

Petra Cagnardi,

University of Milan, Italy

${ }^{*}$ Correspondence:

Yiming Liu

liuyiming@caas.cn

Xiubo $\mathrm{Li}$

lixiubo@caas.cn

tThese authors have contributed equally to this work and share first

authorship

Specialty section:

This article was submitted to

Veterinary Pharmacology and

Toxicology,

a section of the journal

Frontiers in Veterinary Science

Received: 27 January 2021

Accepted: 14 May 2021

Published: 14 June 2021

Citation:

Wang H, Chen C, Chen X, Zhang J, Liu Y and LiX (2021) PK/PD Modeling

to Assess Rifaximin Clinical Dosage in

a Mouse Model of Staphylococcus

aureus-Induced Mastitis.

Front. Vet. Sci. 8:651369.

doi: 10.3389/fvets.2021.651369

\author{
Honglei Wang ${ }^{\dagger}$, Chen Chen ${ }^{\dagger}$, Xiaojie Chen, Jingju Zhang, Yiming Liu* and Xiubo Li* \\ National Feed Drug Reference Laboratories, Feed Research Institute, Chinese Academy of Agricultural Sciences, Beijing, \\ China
}

Staphylococcus aureus (S. aureus) is a common pathogen that causes mastitis, an infection of the milk-secreting tissue of the udder, in dairy cows, and presents a huge economic problem for the dairy industry worldwide. Thus, control and treatment of mastitis in dairy cows is vital in order to reduce the costs associated with the disease. The main purpose of the current work was to examine the current dosage of rifaximin for the treatment mastitis in cows caused by $S$. aureus using pharmacokinetic/pharmacodynamic integration in a mouse mastitis model. The mouse mastitis model was established via injection of S. aureus Newbould 305 (400 CFU/gland) into the mouse mammary gland. A single dose of $50,100,200$, or $400 \mu \mathrm{g} / \mathrm{gland}$, administered via intramammary infusion, was used to study the pharmacokinetics of rifaximin. The pharmacokinetic parameters were analyzed by non-compartment and non-linear mixed-effect models using Phoenix software (version 8.1; Pharsight, USA). In vivo pharmacodynamics was used to examine 18 therapeutic regimens covering various doses ranging from 25 to $800 \mu \mathrm{g} / \mathrm{gland}$ and three dosing intervals of 8,12 , and $24 \mathrm{~h}$ per $24 \mathrm{~h}$ experiment cycle. The antibacterial effect of rifaximin was elevated with higher concentrations of rifaximin or shorter intervals of administration. The percentage of time that drug concentrations exceeded the MIC during a dose interval (\%T > MIC) was generally $100 \%$ for rifaximin and was not better than $\mathrm{AUC}_{24} / \mathrm{MIC}$ in the sigmoid $E_{\max }$ model of inhibitory effect. The optimal antibacterial effect was $2 \log _{10} \mathrm{CFU} / \mathrm{gland}$ when the magnitude of $\mathrm{AUC}_{24} / \mathrm{MIC}$ reached $14,281.63 \mathrm{~h}$. A total of $14,281.63 \mathrm{~h}$ of $\mathrm{AUC}_{24} / \mathrm{MIC}$ was defined as a target value in the Monte Carlo simulation. The clinically recommended dosage regimen of $100 \mathrm{mg} / \mathrm{gland}$ every $8 \mathrm{~h}$ in 1 day achieved an $82.97 \%$ cure rate for the treatment of bovine mastitis caused by Staphylococcus aureus infection.

Keywords: Staphylococcus aureus, mastitis, rifaximin, PK/PD model, Monte Carlo simulation

\section{INTRODUCTION}

Cow mastitis is an inflammation of the mammary gland that can cause huge economic losses to the dairy cow industry due to the decline in milk quality, treatment costs, and prohibitive labor costs (1-3). Mastitis can be divided into two categories according to clinical characteristics: clinical and subclinical mastitis, both of which are usually caused by bacteria, though some infections are 
due to fungus, yeast, or even algae $(4,5)$. Staphylococcus aureus is a common Gram-positive bacterium and the main pathogenic bacteria that causes cow mastitis (6). Staphylococcus aureus can also invade the epithelial barrier and gain access to internal tissues, and it can infect almost any organ and cause a broad spectrum of diseases including pneumonia, osteomyelitis, sepsis, and endocarditis. Treatment of these infections has been complicated because of its ability to persist in tissues and to evade the host immune response $(7,8)$. Antibiotics are undoubtedly the best method to treat cow mastitis induced by $S$. aureus. Rifaximin is a derivative of rifamycin and has a broad spectrum of antibacterial activity, against Gram-positive and Gram-negative microorganisms, as well as both aerobes and anaerobes (9). Rifaximin has been approved for the treatment of hepatic encephalopathy, bacterial diarrhea, as well as acute and chronic bacterial infection of the gut in humans $(10,11)$. Studies have shown that the bioavailability of rifaximin by oral administration is very low and that it is not absorbed by the intestinal mucosa either in healthy individuals or in those with pathological conditions. Therefore, rifaximin can have local effects in the gut after oral administration (12). In veterinary medicine, rifaximin is a good alternative to metronidazole for the treatment of the chronic enteropathy in dogs (13). Moreover, it is also used for the treatment of endometritis and mastitis in dairy cows $(14,15)$. Rifaximin intramammary infusion (lactating cows or dry cows) has been approved to treat cow mastitis. The currently approved rifaximin intramammary infusion dosage regimen approved for the treatment of bovine $S$. aureus mastitis is $100 \mathrm{mg} /$ gland (16).

Irrational use of antibiotics can lead to the emergence of bacterial resistance; thus, the dosages of antibiotics used in clinical and veterinary medicine should be optimized. Pharmacokinetic and pharmacodynamic (PK/PD) modeling is a particularly good method that can concurrently analyze the time course and the antibacterial effectiveness of a drug. The $\mathrm{PK} / \mathrm{PD}$ method can also elucidate an inadequate daily dose or extended dosing interval under a traditional dosing regimen and provide a better dose regimen for curing bacterial diseases. Animal experiments are indispensable in PK/PD modeling, though using large animals, such as cattle or sheep for mastitis experiments, is very expensive. The mouse model of mastitis has the potential to greatly assist in the development of new drug treatments prior to further testing in clinical trials, to assess the rationality of dosages of current drugs, and to improve our understanding of the relationships between the microbiome, the host immune response, and lactation (17-19). This study was a post-approval study, which was to analyze the population pharmacokinetics of rifaximin in mammary gland tissues of healthy mice and the pharmacodynamics of rifaximin on mammary gland tissues in mice with mastitis induced by $S$. aureus. The pharmacokinetics and pharmacodynamics of rifaximin were then combined using the inhibitory sigmoid $E_{\max }$ model to obtain accurate surrogate PK/PD indexes under different levels of antibacterial activity. The $\mathrm{PK} / \mathrm{PD}$ profiles were extrapolated for the treatment of clinical mastitis in cows, and the clinical dosage regimen was evaluated using the Monte Carlo simulation.

\section{MATERIALS AND METHODS}

\section{Bacterial Strains and Animals}

Staphylococcus aureus Newbould 305 (ATCC 29740), a bacterial strain isolated from a clinical case of cow mastitis in Orangeville, Ontario, Canada, in 1958, was used for the current study. This strain is the standard strain used for inducing experimental intramammary infection (IMI) in cows (20). The strain was provided by Shenzhen Huada Gene Company. In addition, 41 $S$. aureus clinical isolates were collected from dairy farms in Beijing suburbs in 2017-2019. Each of the 41 clinical isolates was isolated from per dairy cow with mastitis separately, which was identified by chromogenic medium, microscope and PCR. These cows had never been treated with rifaximin by the time we collected clinical $S$. aureus isolates. Lactating CD-1 mice, weighing 30-45 g, were purchased from Vital River Laboratories in Beijing China. Mice were raised in a special-pathogen-free (SPF) environment with 1 lactating mouse and 10 suckling mice per cage in a 12:12 light:dark cycle. Mice had free access to food and water. All mouse experiments were approved by the Animal Use and Care Committee of Chinese Academy of Agricultural Sciences, and the guidelines of the American Association for Accreditation of Laboratory Animal Care (AAALAC) were followed during all in vivo procedures (21).

\section{Reagents}

Standard Rifaximin was purchased from Sigma Chemical Company (St. Louis, Missouri, USA). The standard stock solution of rifaximin was prepared in DMSO at $8,000 \mu \mathrm{g} / \mathrm{ml}$ and stored at $-20^{\circ} \mathrm{C}$ until use. Working solutions were prepared daily by appropriate dilution of the stock solution with DMSO. HPLC grade methanol, acetonitrile, and ammonium formate were purchased from Thermo Fisher Technology Co., Ltd. (China).

\section{MIC Test}

Determination of microbial susceptibility was based on the Clinical and Laboratory Standards Institute (CLSI) guideline (22). The broth microdilution method was performed to determine the minimal inhibitory concentration (MIC) of rifaximin to $S$. aureus. The MICs of 41 clinical S. aureus were all determined, and the $\mathrm{MIC}_{50}$ and $\mathrm{MIC}_{90}$ values were calculated. $\mathrm{MIC}_{50}$ and $\mathrm{MIC}_{90}$ indicate inhibition of the growth of a bacterial population by at least 50 and $90 \%$, respectively. The MIC of all bacteria was measured three times: all replicates of a given isolate yielded the same MIC value, which was used for subsequent analysis.

\section{In vitro Time-Killing Curves}

The S. aureus Newbould 305 was cultured overnight, diluted 10fold, exposed to five different rifaximin concentrations of $0.5 \times$, $1 \times, 2 \times, 4 \times$, and $8 \times \mathrm{MIC}$, and grown in a shaker at $37^{\circ} \mathrm{C}$ and a speed of $200 \mathrm{rpm}$. The growth control group was not added with rifaximin, and the other treatments were the same as the experimental group. In vitro time-killing curves were evaluated in the two initial bacterial inoculum of $10^{6}$ and $10^{7} \mathrm{CFU} / \mathrm{ml}$. A $100 \mu \mathrm{L}$ volume of the bacterial solution was diluted using a 10 -fold serial dilution protocol in $0,3,6,9$, and $24 \mathrm{~h}$, and the diluted bacterial solutions were placed on $\mathrm{MH}$ agar plates and 
the bacteria counted. All the $\mathrm{MH}$ agar plates were cultured at $37^{\circ} \mathrm{C}$ for $22-24 \mathrm{~h}$ to allow for bacterial growth prior to counting the bacteria.

\section{Pharmacokinetics of the Mammary Gland}

To determine whether drug concentration in one mammary gland affected drug concentration in the other mammary gland, drug was only administered to one mammary gland, and the drug concentration was determined in both mammary glands. Differences in the drug concentrations were analyzed according to the methods described by $\mathrm{Yu}$ et al. (1). The fourth pair of mammary glands in CD-1 mice are the largest and easiest to distinguish and obtain; thus, the fourth pair of mammary glands were chosen for the pharmacokinetics experiment. Approximately 1-2 h prior to the experiments, 812 day-old offspring were separated from lactating mice. Three mice were selected at each time point. A total of 30 lactating mice were used in this experiment. The mice were anesthetized with pentobarbital, a small opening was made in the mammary duct, and $100 \mu \mathrm{L}$ of rifaximin $(2,000 \mu \mathrm{g} / \mathrm{ml})$ was injected into the mammary duct using a 33-gauge blunt needle under anatomic mirror. The mice were euthanized with $\mathrm{CO}_{2}$ at the corresponding sampling time point. Both the treated and non-treated glands were sampled at $0.08,0.17,0.25,0.5,1,4,8,10,12$, or $24 \mathrm{~h}$ after rifaximin administration. The drug concentrations in the L4 and R4 abdominal glands were determined by HPLC-UV.

Mammary gland PK was carried out in four mice $(n=8$ glands) after a single dose of 50, 100, 200, or $400 \mu \mathrm{g} / \mathrm{gland}$ rifaximin was administered via intramammary infusion into both the L4 and R4 glands (each gland was treated individually). Four mice were selected at each sampling time in every single dosing group. A total of 160 mice were used for 4 dosing groups. The R4 and L4 mammary gland samples were sampled at 0.08, 0.17, 0.25, $0.5,1,4,8,10,12$, or $24 \mathrm{~h}$ after drug administration. All mammary gland samples were processed, and the residual solution was detected by HPLC-UV.

\section{Determination of Rifaximin in Mammary Gland Tissue}

First, mammary gland tissues were homogenized. Then, $0.5 \mathrm{~g}$ of mammary gland tissue homogenate was weighed in a $10 \mathrm{ml}$ polypropylene centrifuge tube, and a $3 \mathrm{ml}$ volume of acetonitrile was added. The mixture was whirled for $1 \mathrm{~min}$ using a vortex meter (IKA, Germany) and centrifuged at 7,104 g for 5 min (Thermo Fisher Scientific, USA). The supernatant was transferred to another polypropylene centrifuge tube, and the remaining residue was extracted again with $3 \mathrm{ml}$ volume of acetonitrile. The two extracted solutions were combined and added to a solid-phase extraction (SPE) cartridge (Oasis HLB $3 c c 60 \mathrm{mg}$, Waters Company, USA). The $3 \mathrm{ml}$ acetonitrile was added in the SPE cartridge to elute, and the eluent was evaporated to dry under a nitrogen stream at $40^{\circ} \mathrm{C}$. The residue was reconstituted in $1 \mathrm{ml}$ methanol and filtered through a $0.22 \mu \mathrm{m}$ nylon syringe filter before analysis by HPLC-UV. The conditions for the HPLC-UV analysis were as follows: separation was obtained with a C18 reverse-phase column (Waters XBridge ShieldRP18 $4.6 \mathrm{~mm} \times 250 \mathrm{~mm}, 5.0 \mu \mathrm{m}$ ) designed to withstand $4,000 \mathrm{psi}$, and injection volume was $20 \mu \mathrm{l}$. The mobile phases were methanol, acetonitrile, and $\mathrm{pH} 7.2$ ammonium formate, and the composition ratio was $31.5: 31.5: 37 \%(\mathrm{~V} / \mathrm{V} / \mathrm{V})$. The analyses were conducted at a flow rate of $1.4 \mathrm{ml} / \mathrm{min}$ in isocratic elution. The running time for one injection was $10 \mathrm{~min}$.

The limits of detection (LOD) and the limits of quantitation (LOQ) were determined via the extracted free mammary gland spiked with known concentrations of rifaximin. The accuracy and precision were determined via the blank mammary gland spiked with three concentrations $(10,50$, or $100 \mu \mathrm{g} / \mathrm{g})$ in five replicates for consecutive 5 days. The recoveries and relative standard deviations (RSD) were calculated to evaluate the accuracy and precision, respectively. The RSD was calculated by $\operatorname{RSD}(\%)=[\mathrm{SD} / \mathrm{M}] \times 100 \%$, where SD represents the standard deviation, and $\mathrm{M}$ represents the mean concentration of replicates.

TABLE 1 | The MIC of rifaximin against 41 clinical isolates.

\begin{tabular}{|c|c|c|c|c|c|}
\hline Name of bacteria & MIC $(\mu \mathrm{g} / \mathrm{ml})$ & Name of bacteria & $\operatorname{MIC}(\mu \mathrm{g} / \mathrm{ml})$ & Name of bacteria & $\operatorname{MIC}(\mu \mathrm{g} / \mathrm{ml})$ \\
\hline BJK8C049 & 0.031 & BJG7C046 & 0.031 & BJB8C035 & 0.031 \\
\hline BJK8C055 & 0.063 & BJG7C052 & 0.063 & BJN8C130 & 0.031 \\
\hline BJK8C060 & 0.125 & BJG7C056 & 0.125 & BJN8C133 & 0.031 \\
\hline BJK8C063 & 0.031 & BJG7C065 & 0.031 & BJN8C141 & 0.063 \\
\hline BJK8C018 & 0.031 & BJG7C066 & 0.031 & BJN8C151 & 0.031 \\
\hline BJN8C012 & 0.063 & BJG7C068 & 0.031 & BJN8C152 & 0.031 \\
\hline BJN8C018 & 0.063 & BJG7C070 & 0.031 & BJN8C154 & 0.031 \\
\hline BJN8C021 & 0.063 & BJG7C074 & 0.125 & BJN8C155 & 0.063 \\
\hline BJN8C036 & 0.063 & BJG7C076 & 0.031 & BJN8C174 & 0.125 \\
\hline BJN8C041 & 0.031 & BJG7C077 & 0.031 & BJD8C026 & 0.031 \\
\hline BJN8C054 & 0.063 & BJG7C080 & 0.031 & BJD8C027 & 0.031 \\
\hline BJG7C039 & 0.031 & BJG7C082 & 0.031 & BJD8C030 & 0.031 \\
\hline BJG7C040 & 0.063 & BJG7C084 & 0.031 & BJB7C017 & 0.031 \\
\hline BJB7C018 & 0.063 & BJB7C021 & 0.031 & & \\
\hline
\end{tabular}




\section{Pharmacodynamics Trial}

The S. aureus Newbould 305 was cultured overnight, diluted appropriately, and injected into the mammary gland after mice were anesthetized with pentobarbital, at a concentration of $400 \mathrm{CFU} /$ gland, through a microinjector under an anatomic microscope. The number of bacteria should have reached about $7 \log _{10} \mathrm{CFU} /$ gland after $9 \mathrm{~h}$ of growth in vivo $(23,24)$. A $100 \mu \mathrm{L}$ volume of rifaximin was injected into the $\mathrm{L} 4$ and R4 mammary glands of each mouse through a microinjector under an anatomic microscope. A total of 18 dose groups were included in the experimental study. There were three mice in each dose group. Fifty-four lactating mice were used in this experiment. Before administrating rifaximin, the mice were anesthetized with pentobarbital. The treatment dose ranged from 25 to $800 \mu \mathrm{g} / \mathrm{gland}$, and the interval of administration was 8,12 , or $24 \mathrm{~h}$. The mice were euthanized with $\mathrm{CO}_{2} 24 \mathrm{~h}$ after treatment, and then the mammary gland tissues of mouse were collected for bacterial count before administration and after $24 \mathrm{~h}$. The mammary gland of mice was homogenized by tissue homogenizer, and the homogenate was diluted in a 10fold serial protocol to count the bacteria. The mammary glands of mice in the non-treated control group were also collected for bacterial count. The pharmacodynamics of rifaximin was

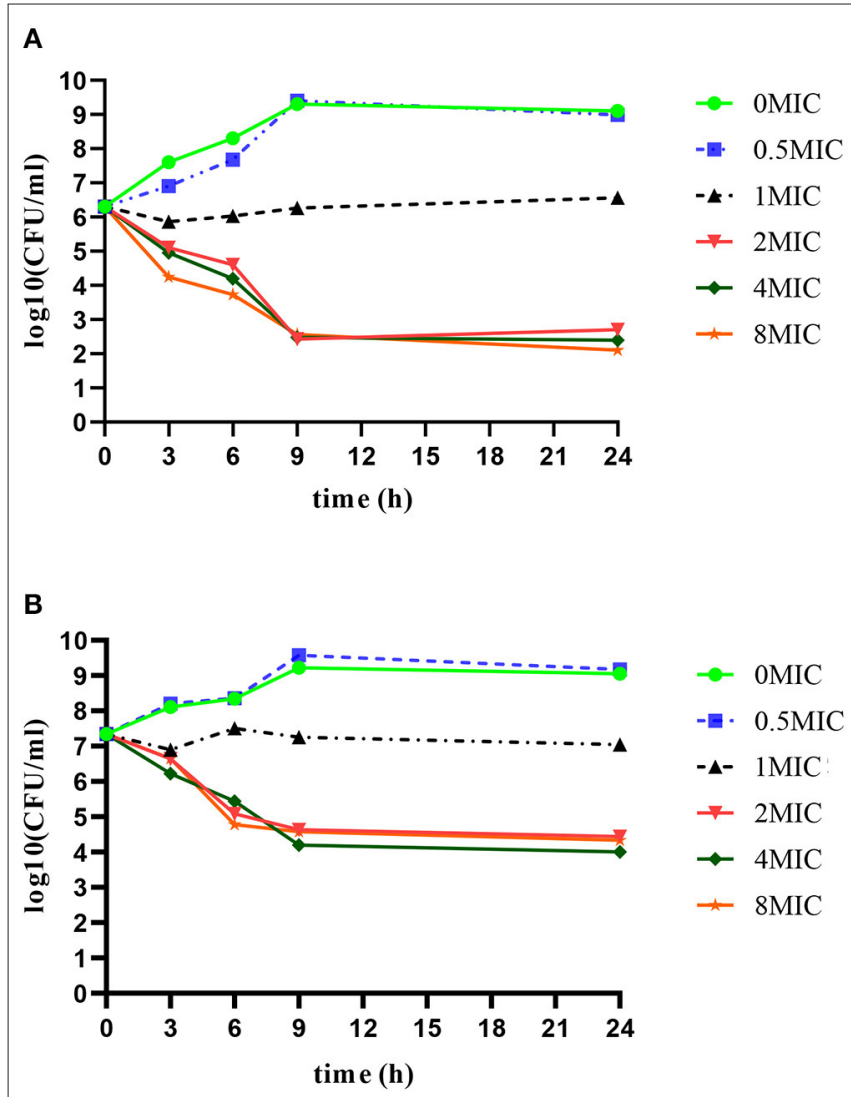

FIGURE 1 | In vitro time bactericidal curve of rifaximin against $S$. aureus Newbould305 with different initial bacterial load. (A) 106 CFU/ml initial inoculum group. (B) 107 CFU/ml initial inoculum group. expressed as the decrease in bacteria in mammary gland tissues $\left(\Delta \log _{10} \mathrm{CFU} /\right.$ gland).

\section{PK/PD Analysis}

The pharmacokinetic parameters of mammary gland tissues were analyzed by non-compartment and a non-linear mixedeffect model using Phoenix software (version 8.1; Pharsight, USA). The PK/PD parameters, including $\mathrm{AUC}_{24} / \mathrm{MIC}$ (the ratio of area under the concentration-time curve over $24 \mathrm{~h}$ to the $\mathrm{MIC}$ ), \% $>$ MIC (the percentage of time duration of drug concentration exceeding the MIC during a dose interval), and $\mathrm{C}_{\text {max }} / \mathrm{MIC}$ (the ratio of peak concentration divided by the MIC), were used as surrogate markers of antibacterial efficacy. The pharmacokinetic parameters of multi-dose administration were obtained by extrapolating the corresponding single dose. The sigmoid $E_{\max }$ model of inhibitory effect was used to analyze the antimicrobial effect of rifaximin (25), and was described as:

$$
E=E_{\max }-\frac{\left(E_{\max }-E_{0}\right) \times C_{e}^{N}}{E C_{50}^{N}+C_{\mathrm{e}}^{N}}
$$

$E$ is the antibacterial effect, which represents changes in the number of bacteria ( $\log _{10} \mathrm{CFU} /$ gland) in the gland sample after $24 \mathrm{~h}$ of treatment compared to the initial colony counts; $E_{\max }$ is the $\log _{10} \mathrm{CFU} /$ gland in the drug-free control sample; $E_{0}$ is the $\log _{10} \mathrm{CFU} / \mathrm{gland}$ in the test sample containing rifaximin, when the maximum antibacterial effect was achieved; $C_{e}$ is the $\mathrm{PK} / \mathrm{PD}$ index $\left(\mathrm{AUC}_{24} / \mathrm{MIC}, C_{\max } / \mathrm{MIC}, \% \mathrm{~T}>\mathrm{MIC}\right) ; E C_{50}$ is the value of $\mathrm{PK} / \mathrm{PD}$ index of drug producing $50 \%$ of the maximum antibacterial effect; and $N$ is the Hill coefficient, which describes the steepness of the concentration-effect curve.

\section{Monte Carlo Simulation}

Three required parameters must be provided for Monte Carlo simulation, using Crystal Ball Professional V7.2.2 software, to perform 10,000 sessions: $\mathrm{PK} / \mathrm{PD}$ target magnitude, the AUC in cow milk, and the prevalence and distribution of MIC. Based on our team's previous PK study of rifaximin in cows, the AUC of the milk sample was assumed to be lognormal distribution with a mean value and standard deviation of $340.73 \pm 43.968 \mathrm{~h} \cdot \mu \mathrm{g} / \mathrm{ml}$. The prevalence and distribution of MIC of clinical $S$. aureus being 0.031, 0.063, and $0.125 \mu \mathrm{g} / \mathrm{ml}$ were $0.634,0.268$, and 0.098 , respectively. The target values of AUC/MIC for $1.5 \log _{10} \mathrm{CFU} /$ gland or $2 \log _{10} \mathrm{CFU} /$ gland bacterial reduction were obtained in the mouse mastitis model experiment using the sigmoid $E_{\max }$ model of inhibitory effect. Thus, the efficacy probability of clinical $100 \mathrm{mg} /$ gland of rifaximin by mammary gland injection at different administration intervals could be obtained, and was defined as the probability of target attainment (PTA).

\section{RESULTS}

\section{Distribution of MICs}

The MICs of 41 strains of mastitis bacterial isolates ranged from 0.031 to $0.125 \mu \mathrm{g} / \mathrm{ml}$, the $\mathrm{MIC}$ of the 
TABLE 2 | The average recovery, intra RSD and inter RSD of rifaximin in mammary gland at three spiked concentration.

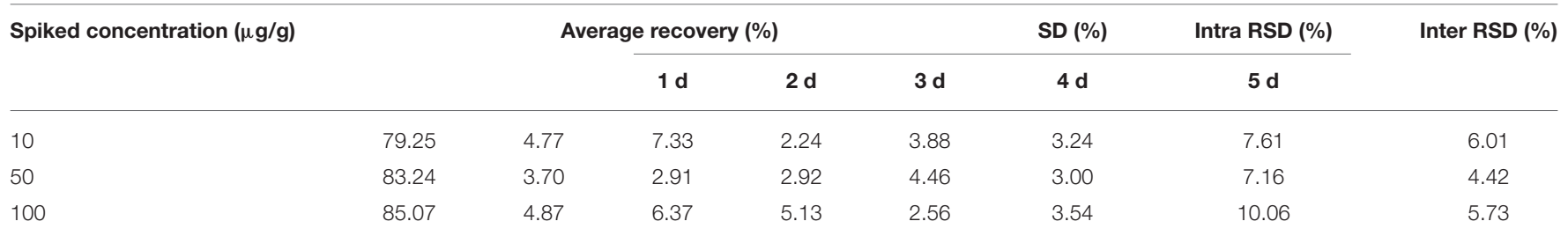
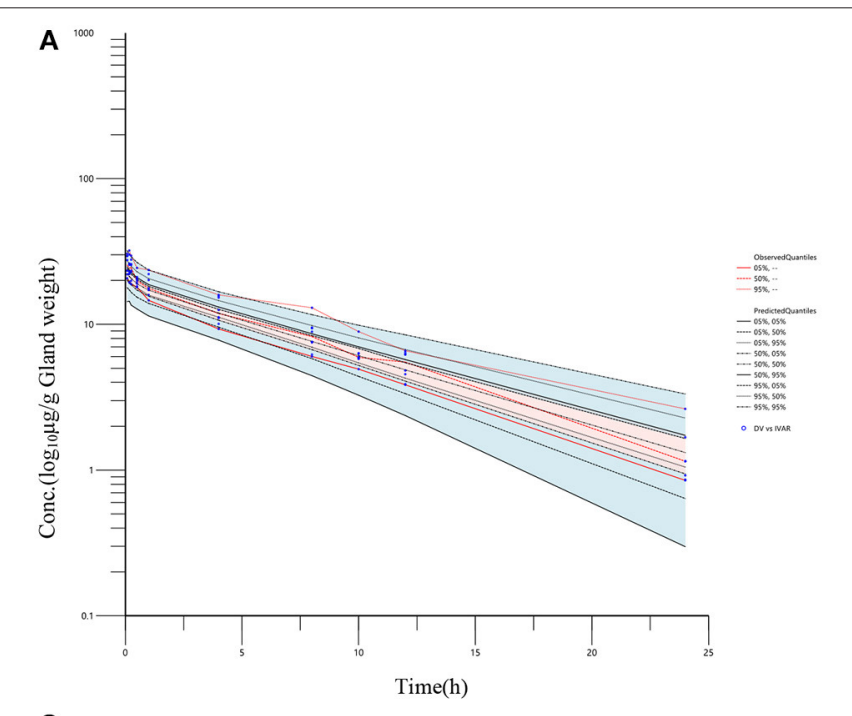

B

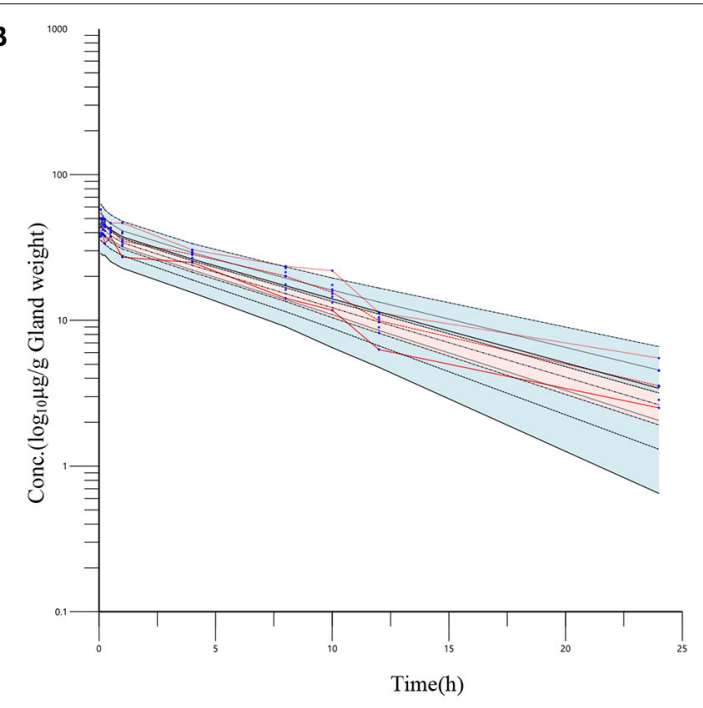

C

D
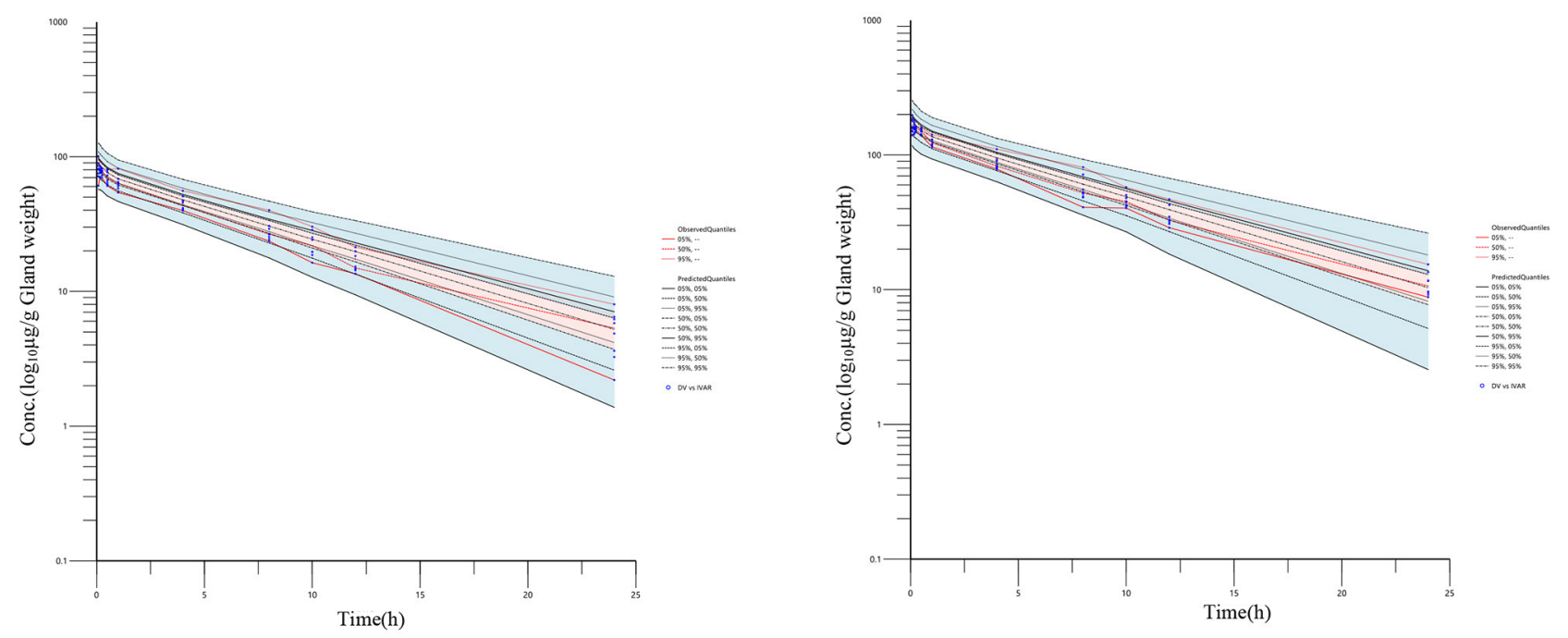

FIGURE 2 | Rifaximin concentration vs. time profile in mammary gland following an intramammary administration dose of 50, 100, 200, and 400 $\mu \mathrm{g} / \mathrm{gland}$. Plotted symbols show the observed concentration data, and the lines show the results of visual predictive checks. For simulated data, the 5th, 50th and 95th percentiles of the final model simulated data are displayed; for real data, the 5th, 50th, and 95th percentiles of the observed concentrations are displayed. (A-D represents 50, 100, 200 , and $400 \mu \mathrm{g} / \mathrm{gland}$, respectively).

S. aureus reference strain $0.0625 \mu \mathrm{g} / \mathrm{ml}$, and the detailed MIC of each clinical strain is shown in Table 1. The $\mathrm{MIC}_{50}$ and $\mathrm{MIC}_{90}$ of the 41 strains of mastitis bacterial isolates were calculated as 0.031 and $0.063 \mu \mathrm{g} / \mathrm{ml}$, respectively.

\section{In vitro Time Killing Curves of Rifaximin Against Different Inoculum Loads}

Time killing curves of rifaximin in vitro were determined in $10^{6} \mathrm{CFU} / \mathrm{ml}$ and $10^{7} \mathrm{CFU} / \mathrm{ml}$ initial S. aureus Newbould 305 inocula and are shown in Figure 1. The bactericidal effect of 
TABLE 3 | The main pharmacokinetic parameters of rifaximin in mammary gland following an intramammary administration with single dose of $50,100,200$, and 400 $\mu \mathrm{g} / \mathrm{gland}$ in mice and analyzed by non-compartment model.

\begin{tabular}{|c|c|c|c|c|c|}
\hline \multirow[t]{2}{*}{ Parameters } & \multicolumn{4}{|c|}{ Administered dose ( $\mu$ g/gland) $(n=8)$} & \multirow[b]{2}{*}{ Mean \pm SD } \\
\hline & 50 & 100 & 200 & 400 & \\
\hline \multicolumn{6}{|c|}{ Non-compartment model } \\
\hline $\mathrm{T}_{1 / 2}(\mathrm{~h})$ & 5.98 & 6.60 & 6.16 & 6.77 & $6.38 \pm 0.37$ \\
\hline MRT (h) & 6.66 & 6.97 & 6.65 & 6.84 & $6.78 \pm 0.15$ \\
\hline $\mathrm{AUC}_{24}(\mathrm{~h} \cdot \mu \mathrm{g} / \mathrm{g})$ & 176.83 & 373.35 & 602.01 & $1,215.86$ & \\
\hline$C_{\max }(\mu \mathrm{g} / \mathrm{g})$ & 25.82 & 45.32 & 80.52 & 165.23 & \\
\hline
\end{tabular}

rifaximin on $S$. aureus showed a time-dependent relationship, as the killing speed did not change, and the killing level was maintained when the concentration of rifaximin reached more than two MIC. Initial S. aureus Newbould 305 inocula of $10^{6} \mathrm{CFU} / \mathrm{ml}$ and $10^{7} \mathrm{CFU} / \mathrm{ml}$, treated with $2 \mathrm{MIC}$ and higher concentrations of rifaximin, decreased by $4 \log \mathrm{CFU} / \mathrm{ml}$ and $3 \log \mathrm{CFU} / \mathrm{ml}$, respectively; however, the bacteria continued to grow when the initial concentration of rifaximin was below the MIC. The bacterial killing rate (CFU/h) during the initial $9 \mathrm{~h}$ of exposure to rifaximin was calculated. The bacterial killing rate of $10^{6} \mathrm{CFU} / \mathrm{ml}$ initial inoculum was almost $2.1 \times 10^{5} \mathrm{CFU} / \mathrm{h}$ at $2 \times$ MIC, $4 \times \mathrm{MIC}$, and $8 \times$ MIC during the initial $9 \mathrm{~h}$ of exposure to rifaximin. The bacterial killing rate of $10^{7} \mathrm{CFU} / \mathrm{ml}$ initial inoculum was almost $2.4 \times 10^{6} \mathrm{CFU} / \mathrm{h}$ at $2 \times \mathrm{MIC}, 4 \times$ $\mathrm{MIC}$, and $8 \times$ MIC during the initial $9 \mathrm{~h}$ of exposure to rifaximin.

\section{Pharmacokinetics of Rifaximin in Mammary Gland Tissue}

LOD and LOQ were 200 and $400 \mathrm{ng} / \mathrm{g}$, respectively, in the mammary glands. The average recoveries for 10,50 , and $100 \mu \mathrm{g} / \mathrm{g}$ were $79.25 \pm 4.77,83.24 \pm 3.70$, and $85.07 \pm 4.87 \%$, respectively. Furthermore, the ranges of intra RSD and inter RSD were 2.2410.06 and $4.42-6.01 \%$, respectively. Detailed values are shown in Table 2 .

In the pilot study, the rifaximin concentration of the untreated mammary gland was at or below the lower limit of quantification. Four different single doses of rifaximin $(50,100,200$, or 400 $\mu \mathrm{g} /$ gland), given via intramammary administration, were used to study the pharmacokinetics of rifaximin in mammary gland tissue. The concentration of rifaximin at different time points was analyzed using non-compartment and non-linear mixedeffect models. The visual predictive check (VPC) stratified by dose of rifaximin are displayed in Figure 2. Based on the criteria of the smaller Akaike information criterion (AIC) and the better goodness of fit, the two compartments model was selected as the most suitable model for non-linear mixed-effect model. The pharmacokinetic parameters of rifaximin in mammary gland tissue analyzed by non-compartment and the estimative values of fixed effect parameters analyzed by non-linear mixedeffect model are shown in Tables 3, 4, respectively. Elimination half-life $\mathrm{T}_{1 / 2}$ and the mean residence time (MRT) were 6.38, $6.78 \mathrm{~h}$, respectively, when analyzed by non-compartment. PK parameters of multiple doses of rifaximin were extrapolated from the values obtained in the study described above.
TABLE 4 | Population pharmacokinetic parameters of rifaximin in mammary gland using the NONMEM model.

\begin{tabular}{lcccc}
\hline Parameter & Estimate & Units & SD & CV\% \\
\hline V1 & 2.15 & $g$ & 0.07 & 3.22 \\
V2 & 0.46 & $g$ & 0.09 & 18.84 \\
$\mathrm{Cl} 1$ & 0.29 & $\mathrm{~g} / \mathrm{h}$ & 0.00 & 1.57 \\
$\mathrm{Cl} 2$ & 0.89 & $\mathrm{~g} / \mathrm{h}$ & 0.34 & 37.77 \\
$\alpha$ & 2.38 & $1 / \mathrm{h}$ & 0.84 & 35.39 \\
$\mathrm{~B}$ & 0.11 & $1 / \mathrm{h}$ & 0.00 & 2.77 \\
\hline
\end{tabular}

$V_{1}$, Central compartment volume of distribution; $V_{2}$, Peripheral compartment volume of distribution; $\mathrm{Cl}_{1}$, Clearance of the central compartment; $\mathrm{Cl}_{2}$, Intercompartmental distribution; $\alpha$, Distribution rate constant; $\beta$, Elimination rate constant.

\section{Pharmacodynamics of Rifaximin With Different Administration Regimens}

In the study of construction of mastitis mice model, no death was observed within $9 \mathrm{~h}$. All mice developed slight rough pelage and visible swelling of the mammary gland. The mammary gland showed severe clinical signs, such as bloody exudation and dilated vessels after dissection.

The pharmacodynamics of rifaximin with different administration regimens in the mastitis mouse model are expressed by decreases in the bacterial level. The 18 dosing regimens were included 6 doses $(25,50,100,200,400$, and 800 $\mu \mathrm{g} /$ gland) and three dosing intervals $(8,12$, and $24 \mathrm{~h})$. The pharmacodynamics of different administration regimens are shown in Figure 3. In all single-dose groups, the maximum antibacterial effect, $2.5 \log _{10} \mathrm{CFU} /$ gland reduction, was obtained with the highest dose $(800 \mu \mathrm{g} /$ gland $)$. The pharmacodynamics of rifaximin increased as the dosage increased, and an improvement in pharmacodynamics was also found in the 8 and $12 \mathrm{~h}$ dosing interval groups at the end of the experiment. Pharmacodynamics were better in the 8 and $12 \mathrm{~h}$ interval $200 \mu \mathrm{g} /$ gland groups compared with the single-dose 400 and $800 \mu \mathrm{g} /$ gland groups.

\section{Integration of PK/PD Parameters}

The 2 alternative PK/PD parameters, including \% $>$ MIC and $\mathrm{AUC}_{24} / \mathrm{MIC}$, were used in the sigmoid $E_{\max }$ model of inhibitory effect, and the correlation coefficients $\left(\mathrm{R}^{2}\right)$ were 0.57 and 0.97 , respectively. In the mouse mammary glands, the concentration of rifaximin was higher than MIC at all time-points during the 


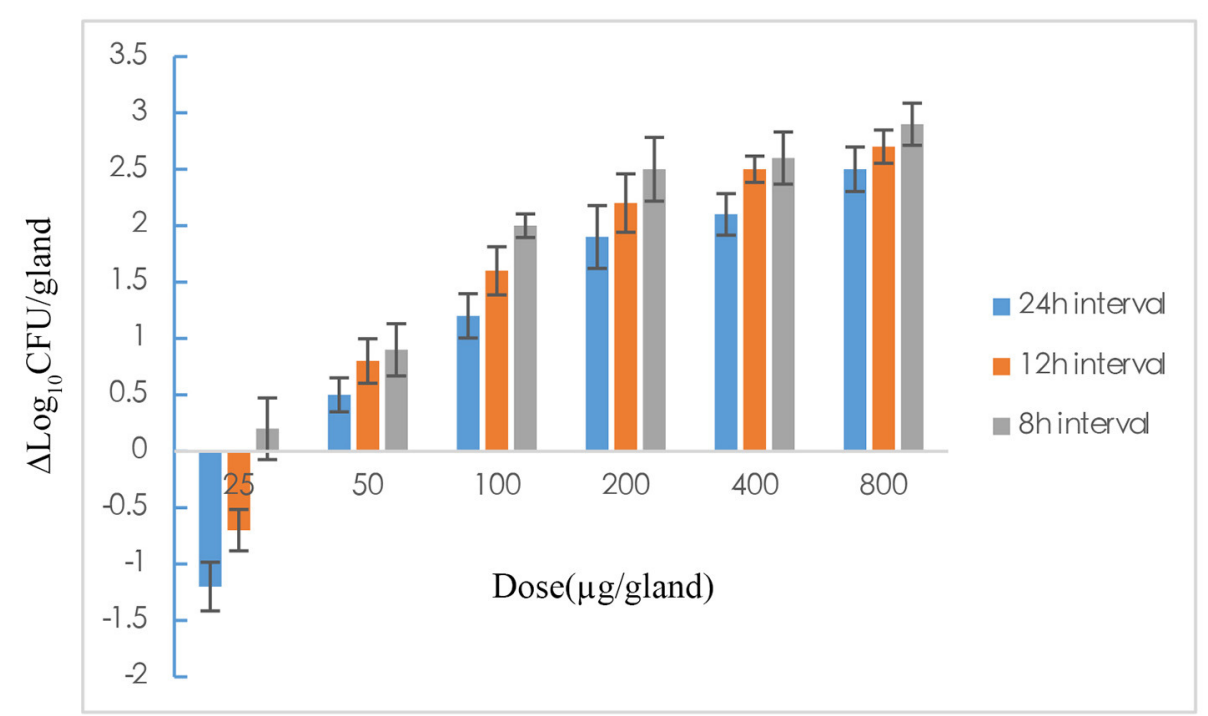

FIGURE 3 | The effect of rifaximin on mastitis induced by Staphylococcus aureus in mouse after 18 dose regimens designed with 25, 50, 100, 200, 400, and 800 $\mu \mathrm{g} / \mathrm{gland}$ and dosing intervals 8,12 , and $24 \mathrm{~h}$, which was expressed as $\Delta \log _{10} \mathrm{CFU} / \mathrm{gland}$.

experimental period, and the $\% \mathrm{~T}>\mathrm{MIC}_{90}$ was $100 \%$ during the $24 \mathrm{~h}$ experimental cycle. Since the correlation between $\% \mathrm{~T}>$ $\mathrm{MIC}_{90}$ and $\Delta \log _{10} \mathrm{CFU} /$ gland was very poor in the sigmoid $E_{\max }$ model of inhibitory $\left(R^{2}=0.57\right)$, the $\mathrm{AUC}_{24} / \mathrm{MIC}_{90}$ was chosen the best alternative parameter and was selected for evaluating the correlation between PK and PD activity in the mammary gland. As shown in Figure 4A, the tail of the simulation curve leveled off when the $\Delta \log _{10} \mathrm{CFU} /$ gland approached the $2 \log _{10} \mathrm{CFU} /$ gland reduction; thus, adding doses was not necessary to achieve a higher antibacterial effect, and the clinical symptoms of redness, swelling, and heat had been significantly improved. Therefore, the $2 \log _{10} \mathrm{CFU} /$ gland reduction was the best in the model and its corresponding $\mathrm{AUC} / \mathrm{MIC}_{90}$ was used as a target value for Monte Carlo simulation. The important parameters in the AUC24/MIC using the inhibitory form $E_{\max }$ sigmoid model after intramammary administration was shown in Table 5.

\section{Monte Carlo Simulation}

The recommended dose of rifaximin for the treatment of cow mastitis is $100 \mathrm{mg} /$ gland (16). Three administration regimens were chosen for the Monte Carlo simulation: one dose was given every 8,12 , or $24 \mathrm{~h}$ so that the total doses in the experimental period were 3,2 , and 1 , respectively. The probability distribution plots of AUC/MIC analyzed by Monte Carlo simulation was shown in Figure 5. When the target value of $\mathrm{AUC}_{24} / \mathrm{MIC}$ was set for a $1.5 \log _{10} \mathrm{CFU} /$ gland decrease, the calculated PTA for the 3dose $/ 24 \mathrm{~h}$ administration was $93.77 \%$, and the PTA for the $2 \log _{10} \mathrm{CFU} /$ gland decrease was $82.97 \%$. The detailed values of PTAs for different treatment schemes are shown in Table 6 and Figure 6.

\section{DISCUSSION}

Mastitis is an inflammatory response resulting from an infection of udder tissue and has been reported in numerous species, including cows, goats, and sheep (26-28). It is very difficult to use cows and goats for studies of mastitis due to problems with management and high costs. Mouse is a typical pattern animal, which is cheap and easy to obtain. Like the dairy cow, it also possesses one teat duct or streak canal per teat. Each mammary gland of the mouse is anatomically and functionally distinct from its neighbor in the same manner as in the dairy cow (29). Many literature reports have confirmed that the pathological phenomena of mammary tissues of mice infected by bacteria are very similar to that of cow mastitis, such as neutrophil infiltration, tissue damage, etc. (24). The results obtained from the mouse mastitis model can provide basis and inspiration for the treatment of cow mastitis. Therefore, mice models are often used to study mastitis. In 1970, Chandler et al. (29) first developed a mouse model of mastitis induced by bacteria, including S. aureus, Streptococcus agalactiae, Corynebacterium pyogenes, Escherichia coli, and Pseudomonas aeruginosa. The $S$. aureus mastitis mouse model was then successfully established by many researchers and has been used to study the pathogenesis of cow mastitis and the anti-inflammatory signal pathway of some natural active ingredients such as Salidroside and Allicin (3032). The mouse model was also used to define drugs disposition and $\mathrm{PK}$ profile. Yu studied the pharmacokinetics of cefquinome in the mammary gland of mice to simulate its pharmacokinetics in dairy cows $(1,25)$. In this study, $400 \mathrm{CFU} /$ gland of $S$. aureus Newbould 305 were injected into one mammary gland of each mouse. After $9 \mathrm{~h}$ of growth in vivo, the number of bacteria had reached about $7 \log _{10} \mathrm{CFU} /$ gland, which was consistent with results in a study by $\mathrm{Yu}$ et al. (23). The feed intake, water 


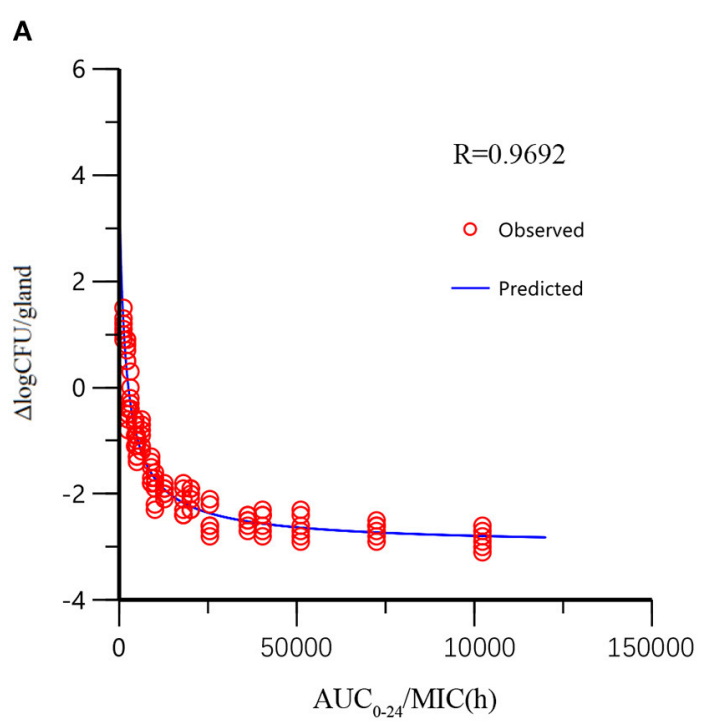

B

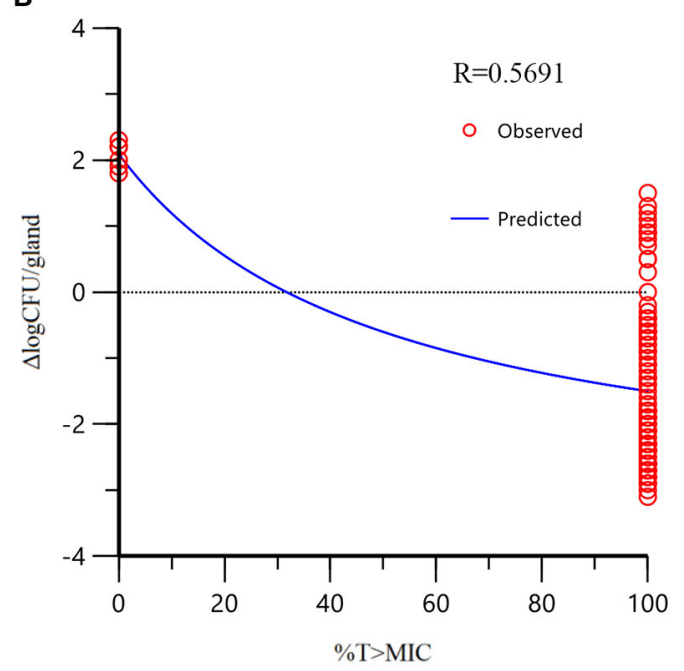

FIGURE 4 | The relationship between PK/PD parameters and bactericidal effect of rifaximin ( $\left.\Delta \log _{10} \mathrm{CFU} / \mathrm{gland}\right)$ analyzed by the sigmoid model. The dots represented the antibacterial effect of rifaximin ( $E=$ final $\log _{10} \mathrm{CFU} / \mathrm{gland}-$ initial $\log _{10} \mathrm{CFU} / \mathrm{gland}$ ) and the line represented the predicted value of $E$. The correlation of $\% \mathrm{~T}>\mathrm{MIC}$ with $\Delta \log _{10} \mathrm{CFU} / \mathrm{gland}$ was very low because of the distribution of $\% \mathrm{~T}>\mathrm{MIC}$ (either 100 or $0 \%$ ), which was not appropriate for PK/PD integration (there are only two independent values, so $R^{2}$ has no meaning for $\% \mathrm{~T}>\mathrm{MIC})$.

intake, and activity of the mice infected with bacteria decreased significantly. Mammary gland redness and swelling were noted with some glands feeling very hard. In addition, the milk from some of the mammary glands had a foul odor. These clinical symptoms were consistent with previous reports (33-35). These characteristics further confirmed the successful establishment of a mouse mastitis model that could be used in the subsequent rifaximin pharmacodynamic studies.

In the MIC study, the MIC of rifaximin against $S$. aureus ranged from 0.031 to $0.125 \mu \mathrm{g} / \mathrm{ml}$, but was mainly distributed
TABLE 5 | The important parameters in the $\mathrm{AUC}_{24} / \mathrm{MIC}$ using the inhibitory form $E_{\text {max }}$ sigmoid model after intramammary administration.

\begin{tabular}{lc}
\hline Parameters & $\mathbf{A U C}_{\mathbf{2 4}}$ /MIC \\
\hline $\log E_{\max }\left(\log _{10} \mathrm{CFU} /\right.$ gland $)$ & $4.33 \pm 2.00$ \\
$\log E_{\max }-\log E_{0}\left(\log _{10} \mathrm{CFU} /\right.$ gland $)$ & $7.32 \pm 2.14$ \\
$E C_{50}(\mathrm{~h})$ & $1,734.33 \pm 1,004.34$ \\
For1.5 $\log _{10} \mathrm{CFU} /$ gland reduction & $8,173.48$ \\
For2 $\log _{10} \mathrm{CFU} /$ gland reduction & $14,281.63$ \\
Slope $(N)$ & $0.88 \pm 0.18$ \\
\hline
\end{tabular}

at $0.031 \mathrm{mg} / \mathrm{ml}$, which was similar to results reported in previous papers $(36,37)$. The $\mathrm{MIC}_{50}$ and $\mathrm{MIC}_{90}$ were calculated with 0.031 and $0.063 \mu \mathrm{g} / \mathrm{ml}$, respectively, and the $\mathrm{MIC}_{90}$ of $0.063 \mu \mathrm{g} / \mathrm{ml}$ was used in the PK/PD model. The in vitro timekilling curves indicated that the $2 \mathrm{MIC}$ and higher concentrations had bactericidal effects as shown by the $4 \log _{10} \mathrm{CFU} / \mathrm{ml}$ reduction in the $10^{6} \mathrm{CFU} / \mathrm{ml}$ initial inoculum group and the $3 \log _{10} \mathrm{CFU} / \mathrm{ml}$ reduction in the $10^{7} \mathrm{CFU} / \mathrm{ml}$ initial inoculum group. A higher initial bacteria inoculum may require a higher concentration of antibiotic or a longer exposure time to the antibiotic. Buldain made a time-kill curve for the effect of rifaximin on $S$. aureus ATCC 29213 at $\mathrm{pH}$ 5.0. They found an almost $4 \log _{10} \mathrm{CFU} / \mathrm{ml}$ reduction in the $10^{6} \mathrm{CFU} / \mathrm{ml}$ initial inoculum group with $2 \mathrm{MIC}$ or higher concentrations of rifaximin; however, rifaximin did not inhibit the growth of bacteria when the concentration was below the MIC (36). These results are consistent with those of the current study, showing that the effect of rifaximin is time dependent. In the in vivo pharmacodynamics experiment in this study, the efficacy of rifaximin increased with the increase in dosage, and the shortened administration interval, and the maximum antibacterial effect of $2.9 \log _{10} \mathrm{CFU} /$ gland was found with a dosage of $800 \mu \mathrm{g} /$ gland given at an $8 \mathrm{~h}$ dosing interval. $\mathrm{Yu}$ et al. (1) studied the pharmacodynamics of cefquinome on mouse mastitis induced by $S$. aureus Newbould 305 and found a maximum antibacterial effect of almost $2 \log _{10} \mathrm{CFU} /$ gland with $800 \mu \mathrm{g} / \mathrm{gland}$ and an $8 \mathrm{~h}$ dosing interval.

In the pilot study of rifaximin in mammary gland, the concentration of rifaximin of the untreated mammary gland homogenate was lower than or equal to the limit of quantitation, which is consistent with the blood-milk barrier (4). The bloodmilk barrier is formed by mammary gland secretory cells that are closely linked together at their apex by tight junctions, which helps prevent the selective diffusion of drugs between the blood and mammary gland $(38,39)$. Therefore, the PK parameters in the mammary gland were used for the PK/PD model and Monte Carlo simulation to evaluate and develop a rational regimen for clinical administration of rifaximin.

The results of the pharmacokinetics study in the mouse model showed the elimination half-life $\left(\mathrm{T}_{1 / 2}\right)$ and mean retention time (MRT) were 6.38 and $6.78 \mathrm{~h}$ for the non-compartment model, indicating that rifaximin can reach a high concentration that is maintained for a long time in the mammary glands of mice, while the $\mathrm{T}_{1 / 2}$ and MRT were 5.57 and $7.39 \mathrm{~h}$ in the cow milk as analyzed by non-compartment model. By comparing 
$\mathrm{T}_{1 / 2}$ and MRT in the mice and cow milk, it concludes the disposition of rifaximin PK data in the mouse mammary gland is similar to rifaximin in milk though there are some anatomical differences between mice and cows. Since dairy cows are so important economically, the withdrawal period for milk after rifaximin should be as short as possible. Depletion experiments were also carried out in dairy cows after rifaximin mammary gland injection, and the results showed that the withdrawal period for milk was $95.1 \mathrm{~h}$, which is in accordance with $96 \mathrm{~h}$ regulation of the European Veterinary Drug Commission (16). Our pharmacokinetic data in milk have not been published yet, and will be published in another paper.

As shown in Figure 3, the antibacterial effect of rifaximin increased slowly when the dosage was over $200 \mu \mathrm{g} / \mathrm{gland}$, indicating that the 400 and $800 \mu \mathrm{g} /$ gland dose regimens were much higher than required to treat mastitis in the mouse model. In Figure 4A, when the $\Delta \log _{10} \mathrm{CFU} / \mathrm{ml}$ reduction reached two, the antibacterial effect of rifaximin was at a stable level even when the $\mathrm{AUC}_{24} / \mathrm{MIC}$ was increasing, and the flat tail of the curve appeared. A more reasonable dosage, one that occurs before the flat tail of the curve appears, should be selected. When the $\Delta \log _{10} \mathrm{CFU} / \mathrm{ml}$ reduction reached two, the knee point of the curve appeared (Figure 4), and the corresponding $\mathrm{AUC}_{24} / \mathrm{MIC}$ value was $14,281.63 \mathrm{~h}$. In the sigmoid $E_{\max }$ model of inhibitory effect, $1.5 \log _{10} \mathrm{CFU} /$ gland was selected as an antibacterial effect value, and the calculated $\mathrm{AUC}_{24} / \mathrm{MIC}$ value was $8,173.48 \mathrm{~h}$. The important parameters in the $\mathrm{AUC}_{24} / \mathrm{MIC}$ using the inhibitory form $E_{\max }$ sigmoid model after intramammary administration are shown in Table 4.

After dividing this value of $14,282 \mathrm{~h}$ by $24 \mathrm{~h}$, we get a scalar (595). It means an average local concentration for the $2 \log 10 \mathrm{CFU} /$ gland is 595 times higher than the MIC of the pathogen in a MHB medium. The reasons for this result are as follows. First, unlike other drugs, rifaximin is administered through intramammary administration instead of the traditional way including intravascular or intramuscular. The drug concentration was measured in the mammary gland tissue, which was much higher than that in blood. Second, the total tissue concentrations largely overestimate the free concentrations. Likely, rifaximin is not dispersed evenly in mammary gland tissue, which may lead to a lower concentration of bacteria exposure. The two reasons accounted for the average local concentration 595 times higher than the MIC of the pathogen to get a maximal efficacy. In the next experiment, we will confirm these two reasons.

In the Monte Carlo simulation, 8,173.48 and 14,281.63 h were used for target value decreases of $1.5 \log _{10} \mathrm{CFU} /$ gland and $2 \log _{10} \mathrm{CFU} /$ gland, respectively. The rifaximin PTAs for 100 $\mathrm{mg} /$ gland administered once, twice, and three times in $24 \mathrm{~h}$ were $62.80,89.06$, and $93.77 \%$, respectively, for a $1.5 \log _{10} \mathrm{CFU} /$ gland decline, and 1.04, 64.11, and 82.97\%, respectively, for a $2 \log _{10} \mathrm{CFU} /$ gland decline. The PTAs for three doses in $24 \mathrm{~h}$ for the decreases of $1.5 \log _{10} \mathrm{CFU} /$ gland and $2 \log _{10} \mathrm{CFU} /$ gland were all higher than for one or two doses in $24 \mathrm{~h}$. Furthermore, the PTAs of three doses in $24 \mathrm{~h}$ for decreases of $1.5 \log _{10} \mathrm{CFU} /$ gland and $2 \log _{10} \mathrm{CFU} /$ gland were all higher than $80 \%$, which is a high cure rate for mastitis. This suggests that a dose of $100 \mathrm{mg} / \mathrm{gland}$

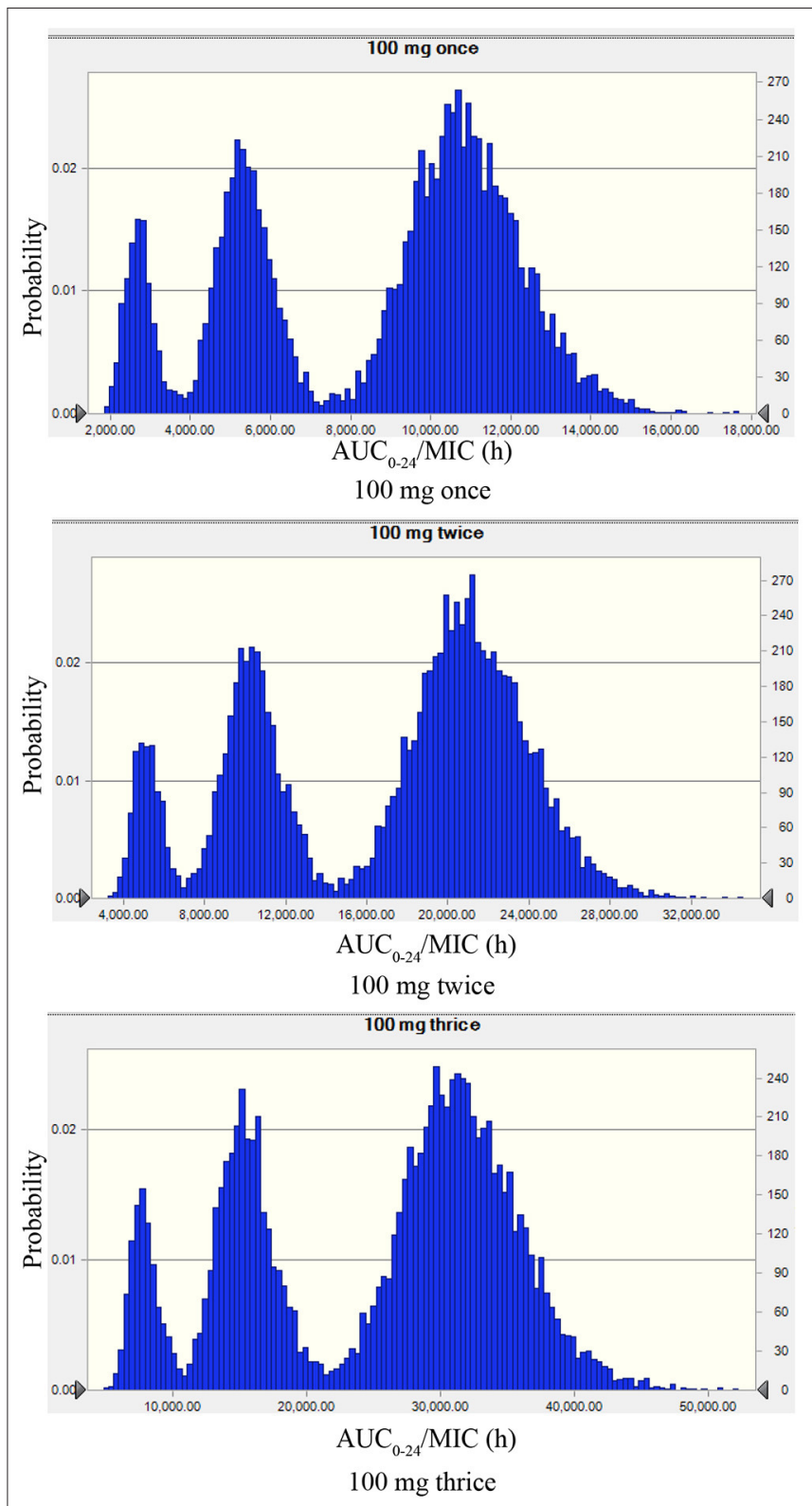

FIGURE 5 | The probability distribution plots of AUC/MIC analyzed by Monte Carlo simulation mimicking rifaximin dosing regimens of $100 \mathrm{mg} / \mathrm{gland}$ by intramammary infusion once, twice, and three times. The peak on the left, the middle, and the right represents the AUC/MIC plotted distribution of the highest MIC $(0.125 \mu \mathrm{g} / \mathrm{ml})$, the median MIC $(0.063 \mu \mathrm{g} / \mathrm{ml})$, and the lowest MIC $(0.031 \mu \mathrm{g} / \mathrm{ml})$.

rifaximin three times a day via mammary gland injection is reasonable and has a significant antibacterial effect.

As the difference of animal species for cows and mice, we can't copy the results of this study of mastitis mice directly to dairy cows with mastitis. But, the magnitude of $\mathrm{PK} / \mathrm{PD}$ parameters in mice can still be capable of defining the PK/PD index required for different efficacy outcomes for mastitis cow since various animal infection models including human should share a relatively similar magnitude of the PK/PD index (40). 


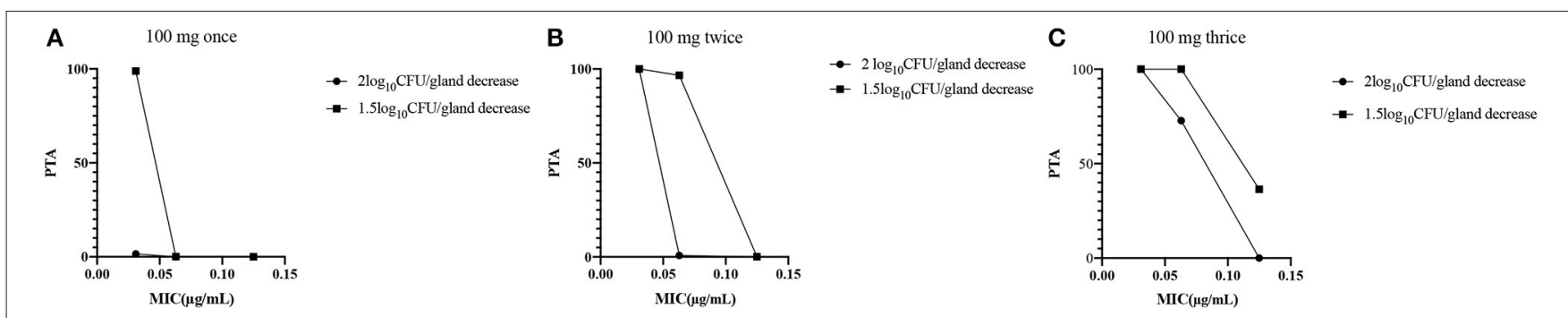

FIGURE 6 | (A) Fractional attainment of the $2 \log _{10}$ CFU/gland decrease for S. aureus $(\bullet)$ and $1.5 \log _{10}$ CFU/gland decrease for $S$. aureus ( $\square$ ) for the 1 -dose (100 $\mathrm{mg} / \mathrm{gland}) / 24 \mathrm{~h}$ administration. (B) Fractional attainment of the $2 \log _{10} \mathrm{CFU} / \mathrm{gland}$ decrease for $\mathrm{S}$. aureus $(\bullet)$ and $1.5 \log _{10} \mathrm{CFU} / \mathrm{gland}$ decrease for $\mathrm{S}$. aureus $(\mathbf{\square})$ for the 2-dose $(100 \mathrm{mg} / \mathrm{gland}) / 24 \mathrm{~h}$ administration. (C) Fractional attainment of the $2 \log _{10} \mathrm{CFU} / \mathrm{gland}$ decrease for $\mathrm{S}$. aureus $(\bullet)$ and $1.5 \log _{10} \mathrm{CFU} / \mathrm{gland}$ decrease for $\mathrm{S}$. aureus ( $\square$ ) for the 3-dose (100 $\mathrm{mg} / \mathrm{gland}) / 24 \mathrm{~h}$ administration.

TABLE 6 | The PTA of AUC/MIC for 1.5 or $2 \log _{10}$ CFU/gland decrease after 100 $\mathrm{mg} / \mathrm{gland}$ once, twice, and thrice by intramammary administration in cows (PTA was defined as the probability of target attainment that the efficacy probability of clinical $100 \mathrm{mg} / \mathrm{gland}$ of rifaximin was obtained by mammary gland injection at different administration intervals).

\begin{tabular}{|c|c|c|}
\hline Dose regimen & $\begin{array}{c}\text { PTA } \\
\text { (1.5 } \log _{10} \text { CFU/gland } \\
\text { decrease) }\end{array}$ & $\begin{array}{c}\text { PTA } \\
\text { (2log10CFU/gland } \\
\text { decrease) }\end{array}$ \\
\hline $100 \mathrm{mg}$ once & $62.80 \%$ & $1.04 \%$ \\
\hline 100 mg twice & $89.06 \%$ & $64.11 \%$ \\
\hline $100 \mathrm{mg}$ thrice & $93.77 \%$ & $82.97 \%$ \\
\hline
\end{tabular}

\section{CONCLUSION}

Based on the in vitro bactericidal curve, rifaximin conformed to a time-dependent antibiotic. When the concentration of rifaximin reached 2MIC, the antibacterial effect did not change even when the concentration increased further; however, the antibacterial effect did increase as the contact time with antibiotics increased. To our knowledge, this is the first study using the PK/PD model to assess the antibacterial effect of rifaximin in a mouse model of mastitis induced by $S$. aureus Newbould 305 . The PK/PD model showed that the $1.5 \log _{10} \mathrm{CFU} /$ gland and $2 \log _{10} \mathrm{CFU} /$ gland decreases corresponded to $\mathrm{AUC}_{24} / \mathrm{MICs}$ of $8,173.48$ and $14,281.63 \mathrm{~h}$, respectively. The $100 \mathrm{mg} /$ gland clinical administration regimen of rifaximin was evaluated by Monte Carlo simulation, and the results showed $100 \mathrm{mg} /$ gland rifaximin, administered three times a day, resulted in 93.77 and $82.97 \%$ cure rates for decreases of $1.5 \log _{10} \mathrm{CFU} /$ gland and $2 \log _{10} \mathrm{CFU} /$ gland in cows with mastitis.

\section{REFERENCES}

1. Yu Y, Zhou YF, Li X, Chen MR, Qiao GL, Sun J, et al. Dose assessment of cefquinome by pharmacokinetic/pharmacodynamic modeling in mouse model of Staphylococcus aureus mastitis. Front Microbiol. (2016) 7:1595. doi: 10.3389/fmicb.2016.01595

\section{DATA AVAILABILITY STATEMENT}

The original contributions presented in the study are included in the article/supplementary material, further inquiries can be directed to the corresponding author/s.

\section{ETHICS STATEMENT}

The animal study was reviewed and approved by the Animal Use and Care Committee of Chinese Academy of Agricultural Sciences.

\section{AUTHOR CONTRIBUTIONS}

$\mathrm{YL}$ and $\mathrm{XL}$ proposed the initial experimental conjecture and experimental feasibility analysis. XC provided the technical guidance for bacterial experiment. HW and CC co-completed the experimental technical route writing and finished the whole experiment work together. JZ participated in the construction of mouse mastitis model. HW and CC completed the analysis of experimental data together. HW wrote the final manuscript. All authors approved the final article.

\section{FUNDING}

This study was supported by the National key R\&D Program (Drug Resistance Database Construction and Ecological Risk Assessment in Livestock and Poultry Breeding Environment) (2016YFD0501305) and Innovation Project of Chinese Academy of Agricultural Sciences (CAAS-FRI-06).

2. LeBlanc SJ, Lissemore KD, Kelton DF, Duffield TF, Leslie KE. Major advances in disease prevention in dairy cattle. J Dairy Sci. (2006) 89:126779. doi: 10.3168/jds.S0022-0302(06)72195-6

3. Motaung TE, Petrovski KR, Petzer IM, Thekisoe O, Tsilo TJ. Importance of bovine mastitis in Africa. Anim Health Res Rev. (2017) 18:5869. doi: 10.1017/S1466252317000032 
4. Gruet P, Maincent P, Berthelot X, Kaltsatos V. Bovine mastitis and intramammary drug delivery: review and perspectives. Adv Drug Deliv Rev. (2001) 50:245-59. doi: 10.1016/S0169-409X(01)00160-0

5. Du J, Wang X, Luo H, Wang Y, Liu X, Zhou X. Epidemiological investigation of non-albicans Candida species recovered from mycotic mastitis of cows in Yinchuan, Ningxia of China. BMC Vet Res. (2018) 14:251. doi: 10.1186/s12917-018-1564-3

6. Wilson GJ, Tuffs SW, Wee BA, Seo KS, Park N, Connelley T, et al. Bovine Staphylococcus aureus superantigens stimulate the entire $\mathrm{T}$ cell repertoire of cattle. Infect Immun. (2018) 86:e00505-18. doi: 10.1128/IAI.00505-18

7. Miller LS, Cho JS. Immunity against Staphylococcus aureus cutaneous infections. Nat Rev Immunol. (2011) 11:505-18. doi: 10.1038/nri3010

8. Wertheim HF, Melles DC, Vos MC, van Leeuwen W, van Belkum A, Verbrugh $\mathrm{HA}$, et al. The role of nasal carriage in Staphylococcus aureus infections. Lancet Infect Dis. (2005) 5:751-62. doi: 10.1016/S1473-3099(05)70295-4

9. Gatta L, Scarpignato C. Systematic review with meta-analysis: rifaximin is effective and safe for the treatment of small intestine bacterial overgrowth. Aliment Pharmacol Ther. (2017) 45:604-16. doi: 10.1111/apt.13928

10. DuPont HL. Review article: the antimicrobial effects of rifaximin on the gut microbiota. Aliment Pharmacol Ther. (2016) 43(Suppl. 1):310. doi: 10.1111/apt.13434

11. Flammini L, Mantelli L, Volpe A, Domenichini G, Di Lecce R, Dondi $\mathrm{M}$, et al. Rifaximin anti-inflammatory activity on bovine endometrium primary cell cultures: a preliminary study. Vet Med Sci. (2018) 4:32632. doi: $10.1002 / \mathrm{vms} 3.115$

12. Calanni F, Renzulli C, Barbanti M, Viscomi GC. Rifaximin: beyond the traditional antibiotic activity. J Antibiot (Tokyo). (2014) 67:66770. doi: $10.1038 /$ ja.2014.106

13. Menozzi A, Dall'Aglio M, Quintavalla F, Dallavalle L, Meucci V, Bertini S. Rifaximin is an effective alternative to metronidazole for the treatment of chronic enteropathy in dogs: a randomised trial. BMC Vet Res. (2016) 12:217. doi: 10.1186/s12917-016-0851-0

14. Rato MG, Bexiga R, Florindo C, Cavaco LM, Vilela CL, SantosSanches I. Antimicrobial resistance and molecular epidemiology of streptococci from bovine mastitis. Vet Microbiol. (2013) 161:286-94. doi: 10.1016/j.vetmic.2012.07.043

15. Sciorsci RL, Piccinno M, Rizzo A. Contractile effect of rifaximin on bovine uterus in the presence of steroid hormone antagonists. Theriogenology. (2018) 110:74-8. doi: 10.1016/j.theriogenology.2017.12.049

16. The European Agency for the Evaluation of Medicinal Products Veterinary Medicines and Inspections. Committee for Veterinary Medicinal Products. Rifaximin Summary Report 3, EMEA/MRL/443/98-FINAL May 1998. London: The European Agency for the Evaluation of Medicinal Products Veterinary Medicines and Inspection (1998).

17. Ingman WV, Glynn DJ, Hutchinson MR. Mouse models of mastitis - how physiological are they? Int Mammary glandfeed J. (2015) 10:12. doi: 10.1186/s13006-015-0038-5

18. Mordmuang A, Brouillette E, Voravuthikunchai SP, Malouin F. Evaluation of a rhodomyrtus tomentosa ethanolic extract for its therapeutic potential on Staphylococcus aureus infections using in vitro and in vivo models of mastitis. Vet Res. (2019) 50:49. doi: 10.1186/s13567-019-0664-9

19. Notebaert S, Meyer E. Mouse models to study the pathogenesis and control of bovine mastitis: a review. Vet Q. (2006) 28:213. doi: 10.1080/01652176.2006.9695201

20. Prasad LB, Newbould FH. Inoculation of the bovine teat duct with Staph. Aureus: the relationship of teat duct length, milk yield and milking rate to development of intramammary infection. Can Vet J. (1968) 9:107-15.

21. National Research Council (US) Institute for Laboratory Animal Research. Guide for the Care and Use of Laboratory Animals. Washington, DC: National Academies Press (US) (1996). 140 p.

22. Clinical Laboratory Standards Institute. Performance Standards for Antimicrobial Disk and Dilution Susceptibility Tests for Bacterial Isolated from Animals; Approved Standard-Fourth Edition and Supplement, VET01A4E and VET01S2E PA (2013).

23. Yu Y, Zhou YF, Chen MR, Li X, Qiao GL, Sun J, et al. In vivo pharmacokinetics/ pharmacodynamics of cefquinome in an experimental mouse model of Staphylococcus aureus mastitis following Intramammary Infusion. PLoS One. (2016) 11:e0156273. doi: 10.1371/journal.pone.0156273
24. Brouillette E, Grondin G, Talbot BG, Malouin F. Inflammatory cell infiltration as an indicator of Staphylococcus aureus infection and therapeutic efficacy in experimental mouse mastitis. Vet Immunol Immunopathol. (2005) 104:1639. doi: 10.1016/j.vetimm.2004.11.006

25. Yu Y, Fang JT, Sun J, Zheng M, Zhang Q, He JS, et al. Efficacy of cefquinome against Escherichia coli environmental mastitis assessed by pharmacokinetic and pharmacodynamic integration in lactating mouse model. Front Microbiol. (2017) 8:1445. doi: 10.3389/fmicb.2017.01445

26. Gomes F, Henriques M. Control of bovine mastitis: old and recent therapeutic approaches. Curr Microbiol. (2016) 72:37782. doi: 10.1007/s00284-015-0958-8

27. Smith MC, Roguinsky M. Mastitis and other diseases of the goat's udder. J Am Vet Med Assoc. (1977) 171:1241-8.

28. Vasileiou NG, Chatzopoulos DC, Sarrou S, Fragkou IA, Katsafadou AI, Mavrogianni VS, et al. Role of staphylococci in mastitis in sheep. J Dairy Res. (2019) 86:254-66. doi: 10.1017/S0022029919000591

29. Chandler RL. Experimental bacterial mastitis in the mouse. J Med Microbiol. (1970) 3:273-82. doi: 10.1099/00222615-3-2-273

30. Brouillette E, Grondin G, Lefebvre C, Talbot BG, Malouin F. Mouse mastitis model of infection for antimicrobial compound efficacy studies against intracellular and extracellular forms of Staphylococcus aureus. Vet Microbiol. (2004) 101:253-62. doi: 10.1016/j.vetmic.2004.04.008

31. Brouillette E, Malouin F. The pathogenesis and control of Staphylococcus aureus-induced mastitis: study models in the mouse. Microbes Infect. (2005) 7:560-8. doi: 10.1016/j.micinf.2004.11.008

32. Chen Y, Wang Y, Yang M, Guo MY. Allicin inhibited Staphylococcus aureusinduced mastitis by reducing lipid raft stability via $\mathrm{LxR} \alpha$ in mice. J Agric Food Chem. (2019) 67:10863-70. doi: 10.1021/acs.jafc.9b04378

33. Geng H, Zou W, Zhang M, Xu L, Liu F, Li X, et al. Evaluation of phage therapy in the treatment of Staphylococcus aureus-induced mastitis in mice. Folia Microbiol (Praha). (2020) 65:339-51. doi: 10.1007/s12223-019-00729-9

34. Hu X, Guo J, Zhao C, Jiang P, Maimai T, Yanyi L, et al. The gut microbiota contributes to the development of Staphylococcus aureus-induced mastitis in mice. ISME J. (2020) 14:1897-910. doi: 10.1038/s41396-020-0651-1

35. Zhang ZB, Guo YF, Li CY, Qiu CW, Guo MY. Selenium influences mmumiR-155 to inhibit inflammation in Staphylococcus aureus-induced mastitis in mice. Food Funct. (2019) 10:6543-55. doi: 10.1039/C9FO01488H

36. Buldain D, Gortari Castillo L, Buchamer AV, Aliverti F, Bandoni A, Marchetti $\mathrm{L}$, et al. Melaleuca armillaris essential oil in combination with rifaximin against Staphylococcus aureus isolated of dairy cows. Front Vet Sci. (2020) 7:344. doi: 10.3389/fvets.2020.00344

37. Pimentel M, Cash BD, Lembo A, Wolf RA, Israel RJ, Schoenfeld P. Repeat rifaximin for irritable bowel syndrome: no clinically significant changes in stool microbial antibiotic sensitivity. Dig Dis Sci. (2017) 62:245563. doi: 10.1007/s10620-017-4598-7

38. Tang X, Liu C, Li T, Lin C, Hao Z, Zhang H, et al. Gambogic acid alleviates inflammation and apoptosis and protects the bloodmilk barrier in mastitis induced by LPS. Int Immunopharmacol. (2020) 86:106697. doi: 10.1016/j.intimp.2020.106697

39. Zonca A, Gallo M, Locatelli C, Carli S, Moroni P, Villa R, et al. Cefquinome sulfate behavior after intramammary administration in healthy and infected cows. J Dairy Sci. (2011) 94:3455-61. doi: 10.3168/jds.20 10-4109

40. Craig WA. Pharmacokinetic/pharmacodynamic parameters: rationale for antibacterial dosing of mice and men. Clin Infect Dis. (1998) 26:1-10; quiz 11-2. doi: $10.1086 / 516284$

Conflict of Interest: The authors declare that the research was conducted in the absence of any commercial or financial relationships that could be construed as a potential conflict of interest.

Copyright (C) 2021 Wang, Chen, Chen, Zhang, Liu and Li. This is an open-access article distributed under the terms of the Creative Commons Attribution License (CC $B Y)$. The use, distribution or reproduction in other forums is permitted, provided the original author(s) and the copyright owner(s) are credited and that the original publication in this journal is cited, in accordance with accepted academic practice. No use, distribution or reproduction is permitted which does not comply with these terms. 